\title{
Yerel Yönetimlerin Spor Politikalarının İncelenmesi (Manisa Büyükşehir Belediyesi Örneği)*
}

\author{
Abdullah KURT ${ }^{1}$ Zeynep ONAĞ $\breve{2}^{\dagger \dagger}$ \\ ${ }^{1}$ Manisa Gençlik ve Spor İl Müdürlüğü, Manisa, https://orcid.org/0000-0003-1833-5995 \\ ${ }^{2}$ Manisa Celal Bayar Üniversitesi, Spor Bilimleri Fakültesi, Manisa, https://orcid.org/0000-0002-4034-6773
}

Orijinal Makale

Gönderi Tarihi: 28.10 .2019
Kabul Tarihi: 19.12.2019
DOI: $10.30769 /$ usbd.639011

Online Yayın Tarihi: 31.12 .2019

\section{$\ddot{O} \mathbf{z}$}

Araştırmanın amacı, Manisa Büyükşehir Belediyesindeki spor politikalarının incelenmesidir. Araştırmanın deseni nitel araştırma yöntemlerinden olgu bilim (fenomeloji) desenidir. Araştırmanın çalışma grubu, 2019 yılı Mart ayı itibariyle Manisa ilinde spor yapılanması ile ilgili birimlerde çalışan, spor konusundaki etkinlikleri düzenleyen ve organizasyonları yapan alanında uzman 5 yöneticidir. Araştırmada, veriler yarı yapılandırılmış görüşme tekniği kullanılarak elde edilmiştir. Görüşmeler, ses kayıt cihazı ve not alma yöntemleri kullanılarak gerçekleştirilmiştir. Araştırmada kullanılan görüşme soruları açı uçlu soru metoduyla oluşturulmuş ve analiz kısmında betimsel veri analizi yönteminden yararlanılmıştır. Yapılan analizler sonucu çalışma beş kategori altında toplanmıştır. Bu kategoriler sırasıyla; belediyelerin spor politikası, spor hizmetleri, kurum ve kuruluşlarla iş birliği, spor örgüt yapısı ve tesislerdir. Araştırmanın sonucunda, Manisa Büyükşehir Belediyesinin spor politikasının, kanun ve mevzuatla sınırlandırılmış yetki ve görevler çerçevesinde spor politikaları olduğu görülmektedir. Bununla beraber, yerel halkı spora teşvik etmek, talep ve ihtiyaçlarını karşılamak, tesis, malzeme ve ulaşım ile ilgili destek sağladıkları görülmektedir. İldeki sporun işlerliği bakımından ise diğer kurum ve kuruluşlara koordineli olarak çalıştıkları sonucuna varılmaktadır.

Anahtar kelimeler: Yerel yönetimler, Spor, Büyükşehir Belediyesi, Spor politikası.

\section{Investigation of Sport Policies of Local Governments (Sample of Manisa Metropolitan Municipality)}

\begin{abstract}
Purpose of this research is investigation of the sport policies in Manisa Metropolitan Municipality. Phenomenology, which is one of the qualitative research methods was used as research design. As of March 2019, the working group of the research consists of 5 people working in the departments of sports structuring in Manisa, organizing activities and organizing sports activities. In the research, the data were obtained by using semi-structured interview technique. Interviews conducted by using voice recorders and note-taking methods. The interview questions which used in the research was formed by the open-ended question method and the content analysis and descriptive data analysis method was used in the analysis part. As a result of the interviews with the participants; the views of the participants were grouped under five headings. These are; sports policy of municipalities, sports services, cooperation with institutions and organizations, sports organization structure and facilities. At the end of the study, it is seen that Manisa Metropolitan Municipality's sports policies are within the framework of powers and duties limited by law and legislation. However, it is seen that municipality encourage local people for sports, meet their demands and needs for sports, and provide support for facilities, materials and transportation. It is concluded that municipality work in coordination with other institutions and organizations in terms of the functioning of sports in the province.
\end{abstract}

Keywords: Local governments, Sports, Metropolitan municipality, Policy of sports.

\footnotetext{
* Bu araştırma MCBÜ Sosyal Bilimler Enstitüsü, Spor Yöneticiliği ABD Yükseklisans Öğrencisi Abdullah Kurt'un "Yerel Yönetimlerin Spor Politikalarının İncelenmesi (Manisa Büyükşehir Belediyesi Örneği)" başlıklı tezinden üretilmiştir.

${ }^{\dagger}$ Sorumlu Yazar: Zeynep ONAĞ, E-posta: zeyneponag@gmail.com.
} 


\section{GíRiş}

İnsanlar, yaşamları boyunca sağlıklı ve kaliteli bir hayat sürmek istedikleri için spor yapmaya olan ihtiyaçları da artmıştır. Hızla gelişen ve buna paralel olarak nüfusun da giderek arttığı dünyada, insanlar yoğun bir tempoda çalışmakla birlikte stresle de mücadele içersindedirler. $\mathrm{Bu}$ nedenle devletler yatırımlarını yaparken insanların ihtiyaçlarını giderebilmesi için spor tesislerine öncelik vermesi, yani insan faktörünü göz ardı etmemesi gerekmektedir (Ceyhun, 2008:325-332). Bu yaklaşım neticesinde, bir taraftan merkezi yönetime bağlı kamu kurum ve kuruluşları karşımıza çıkarken diğer taraftan ise özerk kuruluşların önemi ortaya çıkmaktadır.

\section{Yerel Yönetim Kavramı}

Güncel tanımlara bakıldığında yerel yönetimler, 19. yüzyılın ortalarına doğru devlet içinde hukuki nitelik kazanmıştır. Bu dönemlerde yerel yönetimlerin ortaya çıkışı, bugünkü özelliğine sahip olmasalar da, ilk kez merkezi otoritenin yetkilerinden bir kısmının bazı yerel otoritelere devredilmesinin, bunun yanı sira bazı yerel topluluklara da bu haklardan yararlanma imkânının tanınması sonucu olmuştur (Nadaroğlu, 1994).Yerel yönetimler, belirli bir coğrafi alanda (kent,köy, il vb.) yaşayan kişilerin, bir arada yaşamak nedeniyle kendi ihtiyaçları için hizmet üretmek amacı ile kurulan, karar organları bölgede yaşayanlarca seçilerek göreve getirilen, yasalarla belirlenmiş görevlere ve yetkilere, bütçeye ve personele sahip, üstlendiği hizmetler için kendi kurduğu örgütsel yapısını merkez yönetimi ile ilişkilerinde idari özerklikten yararlanan kamu tüzel kişileridir (Parlak ve Özgür, 2002: 101102). Yerel yönetimler, gelişmiş ve gelişmekte olan bütün ülkelerde halkın ihtiyaçlarının ve beklentilerinin yerine getirilmesi açısından vazgeçilemeyecek kuruluşlar olarak görülmektedir. Bir ülkedeki yerel yönetimlerin gücü ve etkinliği, o ülkenin gelişmişlik ve demokratiklik düzeyi ile yakından ilişkilidir (Arslan, 2005:189-208).

Yerel yönetimlerin varlık sebeplerini açıklarken; Devlet tüm kamu hizmetlerinin ülke ve vatandaş yararına, bazı özerk kuruluşlar tarafından yürütülmesine izin verir. Kimi hizmetler tüm bir ülkeyi değil bir bölgeyi ya da bir kısım vatandaş gruplarını da ilgilendirir. Bu tür hizmetlere karşı devletin kayıtsız kalması beklenemez. Bu nedenle, kendi denetimi altında bazı hizmetleri ayrı bütçesi, tüzel kişiliği ve geliri bulunan özerk kuruluşlara verebilir ifadesiyle konunun farklı bir boyut kazanmasına sebebiyet vermiş̧tir (Keleş ve Yavuz, 1983:20).

Belediyelerin görevleri arasında Büyükşehir'in bütünlüğüne hizmet eden sosyal, sağlık, kültürel, bilim, eğitim alanında, yurt içi ve yurt dışı organizasyon ve faaliyetlerde bulunarak kendi üstüne düşen görev ve sorumlulukları yerine getirmede zorunlu kılınmıştır (5216 sayılı Büyükşehir Belediyesi Kanunu 7. Madde (m) bendi). Aynı zamanda belediyeler, halkın spor ihtiyacını karşılamada önemli sorumluluklar üstlenmiştir. 10.07.2004 tarihinde kabul edilen 5216 sayıl 11 "Büyükşehir Belediyesi kanunun" da;

Büyükşehir, ilçe ve ilk kademe belediyelerinin görev ve sorumluluklarını belirleyen 7. maddesinin, (m) bendinde; "Büyükşehir'in bütünlüğ̈̈ne hizmet eden sosyal donatılar, spor, dinlence, eğlence ve benzeri yerleri yapmak, yaptırmak, işletmek veya işlettirmek; gerektiğinde amatör spor kulüplerine malzeme vermek ve gerekli desteği sağlamak, amatör takımlar arasında spor 
müsabakaları düzenlemek, yurt içi ve yurt dışı müsabakalarda üstün başarl gösteren veya derece alan sporculara belediye meclis kararlyla ödül vermek" görev olarak verilmiştir.

Aynı kanunun 15. maddesinde; "Büyükşehir Belediye Meclisi, her dönem başı toplantısında, üyeleri arasından seçilecek en az beş, en çok dokuz kişiden oluşan ihtisas komisyonları kurabilir "eğitim, kültür, gençlik ve spor komisyonu ile ulaşım komisyonunun kurulması zorunludur" ifadesine yer verilmiştir.

Ilçe ve ilk kademe belediyelerinin görev ve yetkilerini belirleyen kismın; (d) maddesinde; Birinci fikrada "Belirtilen hizmetlerden; otopark, spor, dinlenme ve eğlence yerleri ile parklarl yapmak; yaşlılar, özürlüler, kadınlar, gençler ve çocuklara yönelik sosyal ve kültürel hizmetler sunmak; mesleki ĕgitim ve beceri kursları açmak; să̆lık, ĕgitim, kültür tesis ve binalarının yapım, bakım ve onarımı ile işlevlerinin geliştirilmesine ilişkin hizmetler yapmak" olarak düzenlenmiştir.

Büyükşehir belediyelerinin gelirlerini düzenleyen 23. maddesinin, (d) bendinde; Büyükşehir belediyesine bırakılan sosyal ve kültürel tesisler, spor, eğlence ve dinlenme yerleri ile yeşil sahalar içinde tahsil edilecek her türlü vergi, resim ve harçlarl". Büyükşehir belediyelerinin giderleri düzenleyen 24 maddesinin (o) bendinde ise; "Spor, sosyal, kültürel ve bilimsel etkinlikler için yaplan giderler" olarak düzenlenmiştir. 27. maddesinde ise; "Yeni kurulan büyükşehir belediyelerinde meydan, bulvar, cadde, yol, sokak, park, spor ve kültürel tesislerin büyükşehir belediyesi ile büyükşehir kapsamındaki diğer belediyeler arasında dă̆llımına ilişkin esaslar Büyükşehir Belediye Meclisi tarafindan belirlenir" ifadelerine yer verilmiştir ve bu şekilde bir çok görevi spor hizmetleri adına belediyeler üstlenmiştir (Erişim:05.07.2019 https://www.mevzuat.gov.tr/MevzuatMetin/1.5.5216.pdf/) ifadeleri yer almaktadır.

\section{Yerel Yönetimler Kanunlarında Yerel Yönetimlere Spor Konusunda Düşen Görevler}

Belediyelere spor konusunda düşen görevler 5393 sayılı Belediye kanunda açıkça belirtilmektedir. Kanununda, gençlik ve spor merkezlerini açmak ve yaptırmak ibaresi mevcuttur. Yine aynı kanunda, öğrencilere, amatör spor kulüplerine malzeme yardımı yapılması ve gerekli maddi desteğin sağlanması, her türlü amatör spor organizasyonları düzenlenmesi, yurt içi ve yurt dışı müsabakalarda başarılı olan sporculara belediye meclisi kararıyla ödül verilebileceği belirtilmektedir (5393 sayılı Belediye Kanunu 14. Maddenin (a) ve (b) bendi). Kanunun, 18. maddesinin (p) bendinde ise belediyelere, sanat ve spor gibi alanlarda faaliyet ve projeler gerçekleştirmesine ve bu çerçevede bu organizasyon faaliyetler için arsa, bina ve benzeri tesisleri yapma, yaptırma kiralama veya tahsis etmeye karar verme yetkisi verildiği görülmektedir (5393 sayılı Belediye Kanunu 18. Maddenin (p) bendi). Bununla bereber, 2005 tarihli ve 5393 sayll Belediye Kanunun 37. maddesinde görev başındaki belediye başkanlarının profesyonel spor kulüplerinin idari başkanlığını yapamaz ve yönetiminde de bulunamaz ibaresi yer almaktadır (5393 sayılı Belediye Kanunu 37. Madde)

Belediyelerle ilgili yapılan çalışmalar incelendiğinde; Kurtipek (2019); Dinç, Çolakoğlu ve Kurtipek (2018); Doğu, Kardaş ve Atalı (2013); Sinopluoğlu (2011); Mersinli (2009); Tekin (2013); Esenkaya'nın (2010), çalışmaları olduğu görülmektedir. Manisa ilinde belediyelere yönelik olarak yapılan çalışmalar incelendiğinde, belediyenin spor politikalarının incelendiği bir çalışma olmadığı görülmüştür. Bu bağlamda bu araştırmanın amacı, Manisa ilindeki belediyelerin spor politikalarını incelemek ve önerilerde bulunabilmektedir. 


\section{YÖNTEM}

\section{Araştırmanın Modeli}

Araştırmada, yerel yönetimlerde oluşturulan spor politikaları ve bu politikaların işleyişinin incelenmesi, katılımcıların bu işleyişte nasıl bir rol izlediğini, beklentilerini, önerilerini ve düşüncelerini ortaya çıkartabilmek amacı ile nitel araştırma yöntemlerinden olgu bilim (fenomenoloji) deseni kullanılmıştır. Olgu bilim, farkında olunan, ancak derinlemesine ve ayrıntılı bir anlayışa sahip olunamayan olgulara odaklanma olarak tanımlanmaktadır (Yıldırım ve Şimşek, 2013: 78).

\section{Araştırmanın Çalışma Grubu}

Bu çalışmada amaçlı örneklem yöntemi türlerinden biri olan tipik durum örnekleme tekniği kullanılmıştır. Tipik durum örnekleme yöntemi, bir araştırmada yeni bir uygulama ya da bir yenilik tanıtılmak isteniyorsa veya yeniliğin olduğu durumlarda bu konuda bilgi ve tecrübe sahibi kişiler olması halinde yararlanılmaktadır. Nitel araştırmanın örnek ve bakış açısı oluşturma yoluyla deneyim kazandırma işlevi, bu tür örneklemin kullanıldığı araştırmalarda açık bir biçimde ortaya çıkmaktadır. Bu durumda, belirlenen ölçütü karşılayan kriterlere uygun örnekleme dikkate alınmaktadır (Yıldırım ve Şimşek, 2013: 135-138).

Araştırmanın çalışma grubu; 2019 yılı Mart ayı itibariyle, Manisa ilinde Manisa Büyükşehir Belediyesine bağlı en fazla nüfusa sahip Şehzadeler Belediyesi,Yunusemre Belediyesi, Akhisar Belediyesi ve Turgutlu Belediyesi bünyesinde spor yapılanması ile ilgili birimlerde çalışan, spor konusundaki etkinlikleri düzenleyen ve organizasyonları yapan, bulundukları birimlerde en az 4 yıldır çalışan, yaşları 29 ile 54 arasında değişen ve araştırmaya gönüllü olarak katılmayı kabul eden alanında uzman 5 yöneticiden oluşmaktadır.

Tablo 1: Katılımeı profili

\begin{tabular}{|c|c|c|c|c|c|c|c|c|}
\hline Katılımeı & Yaş & Cinsiyet & $\begin{array}{l}\text { Eğitim } \\
\text { Durumu }\end{array}$ & $\begin{array}{l}\text { Medeni } \\
\text { Durum }\end{array}$ & Mesleği & Görevi & $\begin{array}{l}\text { Görev } \\
\text { Süresi } \\
\text { ( Yıl ) }\end{array}$ & Bağlı Olunan Kurum \\
\hline K1 & 54 & Erkek & Lisans & Evli & $\begin{array}{l}\text { Devlet } \\
\text { Memuru }\end{array}$ & $\begin{array}{l}\text { Spor Şube } \\
\text { Müdürü }\end{array}$ & 8 & $\begin{array}{l}\text { Manisa Büyükşehir } \\
\text { Belediyesi }\end{array}$ \\
\hline K2 & 48 & Erkek & Lisans & Evli & $\begin{array}{l}\text { Devlet } \\
\text { Memuru }\end{array}$ & $\begin{array}{l}\text { Spor işleri } \\
\text { Müdürü }\end{array}$ & 8 & Yunusemre Belediyesi \\
\hline K3 & 47 & Erkek & Lise & Evli & Esnaf & $\begin{array}{l}\text { Belediye Başkan } \\
\text { Yardımcısı }\end{array}$ & 8 & Akhisar Belediyesi \\
\hline K4 & 29 & Erkek & Lisans & Evli & Yönetici & $\begin{array}{l}\text { Kültür ve Sosyal } \\
\text { Müdürlüğ̈ü }\end{array}$ & 5 & Şehzadeler Belediyesi \\
\hline K5 & 34 & Erkek & Lisans & Evli & Avukat & $\begin{array}{l}\text { Belediye Başkan } \\
\text { Yardımcısı }\end{array}$ & 4 & Turgutlu Belediyesi \\
\hline
\end{tabular}

\section{Verilerin Toplanması ve Görüşme Formunun Hazırlanması}

Araştırmada veri toplama yöntemi olarak, "görüşme” yaklaşımından "yarı yapılandırılmış görüşme tekniği”" kullanılmıştır. Araştırmada, katılımcılara kişisel bilgi formu ve yerel yönetimlerde oluşturulan spor politikaları ve bu politikaların işleyişinin incelenmesi ve katılımcıların bu işleyişte nasıl bir rol izlediğini, beklentilerini, önerilerini ve düşüncelerini ortaya çıkartabilmeye yönelik sorular iletilmiştir. Görüşmeler, ses kayıt cihazı ve not alma yöntemleri kullanılarak gerçekleştirilmiştir. Araştırmada kullanılan görüşme soruları yarı yapılandırılmış açık uçlu soru metoduyla oluşturulmuştur. 
Yarı yapılandırılmış görüşme esnasında çalışma grubundaki bireylerin hepsine aynı sorular yöneltilmektedir. Bir konu ve soru listesi sunan yarı yapılandırılmış görüşme formları ise araştırmacıya bu noktada rehberlik etmektedir. Bununla birlikte, görüşme formunun yarı yapılandırılmış olması araştırmacıya görüşmenin yönüne göre değişiklikler yapma bağlamında esneklik sunmaktadır (Bernard, Wutich ve Ryan, 2016: 76).

Soruların oluşturulması kısmında literatür taraması gerçekleştirilmiş ve araştırma sorularının yanıtlanmasını sağlayacağı düşünülen sorular ile taslak bir görüşme formu oluşturulmuştur. Araştırma grubundaki örneklemlerin cevaplarını sınırlı bir çerçeveye oturtmamak için açıklamalarına olanak sağlamak amacıyla görüşme formunda açık uçlu sorulara yer verilmiştir. Araştırma sürecinde verilerinin toplanmasında faydalanılan ve araştırmacılar tarafindan geliştirilmiş olan yarı yapılandırılmış görüşme formu altı açık uçlu sorudan oluşmaktadır.

\section{Verilerin Analizleri}

Araştırmada, betimsel veri analizi yöntemi kullanılmıştır. Nitel verilerin analizinde araştırmacının konuya dair teorik bilgiye sahip olması ve verilerin toplanacağı ortamın çok önemli bir yeri vardır. Betimsel analiz yönteminde ortaya çıkan veriler, daha önceden hazırlanan temalara göre özetlenmekte ve yorumlanmaktadır. Meydana çıkan temaların ilişkilendirilmesi, anlamlandırılması ve ileriye dönük tahminlerde bulunulması da, araştırmacının yapacağı yorumların arasında yer alabilmektedir. Dolayısıyla araştırmada elde edilen verilerin yorumlanması ve bu verilere bir anlam kazandırılması sürecinde betimsel analiz yönteminden yararlanılmaktadır (Yıldırım, Şimşek, 2013: 256).

Araştırma verilerinin elde edilmesi ile birlikte, ses kaydı yapılmış olan veriler yazılı bir metine dönüştürülmüştür. Metin haline getirilen veriler, konunun kuramsal çerçevesi ve oluşturulan başlangıç kod listesi dikkate alınarak kodlanmıştır.

\section{Araştırmacının Konumu}

Nitel araştırmalarda dış güvenirliğin (tekrar edilebilirliğin) sağlanması açısından araştırmacının süreç içerisindeki konumunu açık halde sunması önem taşımaktadır (Yıldırım, Şimşek, 2013: 293-294). Bu çalışmada araştırmanın çerçevelerinin oluşturulması, yürütülmesi, görüşmeler için randevu alınması, görüşmelerin ve analizlerin gerçekleştirilmesi son olarak bulguların raporlaştırılması sürecinde araştırmacı rol almıştır. Görüşmeler araştırmacı tarafından özel olarak yapılmış, alanında uzman kişilerin görüşleri alınarak sonuçlar aktarılmıştır.

\section{Geçerlik ve Güvenirlik}

Tüm bilimsel araştırmalar da olduğu gibi nitel araştırmalarda da sonuçların inandırıcılığı en önemli ölçütlerden birisi olarak kabul edilmektedir. Bu açıdan araştırmalar da en yaygın kullanılan iki ölçüt verilerin geçerlik ve güvenirliği olarak karşımıza çıkmaktadır. Bakıldığı zaman bütün anlamıyla "geçerlik" araştırma sonuçlarının kabul edilebilir olduğunu konu edinir. Elde edilen araştırma sonuçları eş değer grup veya ortamlara aktarılabilirliğine dış 
geçerlik, iç geçerlik ise araştırmanın verilerine ulaşırken ki geçen zamanın çalışılan gerçekliği meydana çıkarmadaki yeterliği ile bağlantılıdır. Güvenirlik ise kısa anlatımla elde edilen araştırma verilerinin tekrar edilebilirliği ile alakalıdır. Dış güvenirlik, elde edilen araştırma sonuçlarının benzer durumlarda aynı sonucu verip vermeyeceğine, iç güvenirlik ise başka çalışma yapan araştırmacıların elde edilen aynı veriden faydalanarak aynı sonuçlara ulaşıp ulaşmayacağı ile ilişkindir (Le Compte ve Goetz, 1982:31-60). Araştırma da öncelikle iç geçerliği oluşturmak amacı ile araştırmanın verileri iki farklı uzman tarafindan incelenmiş, karşılaştırmalar yapılmıştır. Dış geçerliliği sağlamaya yönelik ise diğer araştırmacıların da sonuçları anlamasına ve benzer çalışmalara kolaylık sağlamasına katkıda bulunması için kodların, kategorilerin ve temaların net bir biçimde ve kuramsal çerçeveye uygun olarak tanımlanmasına dikkat edilmiştir. Güvenirliğin sağlanması için araştırmada çalışılan ortamda meydana gelen her şey veri olarak kaydedilmiştir. Ayrıntılı kayıtlar alınmış, alan notlarını katılımcıların da incelemesi sağlanmış, ses kayıtları tutulmuş, katılımcıların kurdukları cümlelerden alıntılar yapılmış ve alıntılar herhangi bir ekleme yapılmaksızın elde edildiği tüm bilgileri ile sunulmuştur.

Çalışmada verilerin elde edilmesine yönelik olarak yüz yüze görüşmelerden yararlanılmıştır. Görüşmelere yönelik olarak ise yarı yapılandırılmış görüşme formu kullanılmıştır. Görüşme formunun oluşturulması sürecinde geçerlik ve güvenirliğin sağlanması amacıyla aşağıdaki adımlar izlenmiştir:

1. Araştırma problemi ve soruları doğrultusunda, literatürden yararlanılarak yirmi açık uçlu sorunun yer aldığ 1 bir soru havuzu oluşturulmuştur.

2. Oluşturulan soru havuzu konu alanında uzman iki öğretim elemanına gönderilerek görüşleri alınmış, öncelikle on soru madde havuzundan çıkartılmış, uzmanlardan gelen dönütler doğrultusunda düzenlemeler yapılarak bir görüşme formu oluşturulmuştur.

3. Uzmanların görüşleri sonucunda elde kalan sorular doğrultusunda görüşme formuna son şekli verilerek, yedi demografik bilgi ve altı görüşme sorularından oluşan yarı yapılandırılmış görüşme formu oluşturulmuştur.

4. Form araştırmanın çalışma grubuna uygulanmadan önce yerel yönetimler konusuna hakim bir spor yöneticisine inceletilerek soruların değerlendirilmesi istenmiş ve soruların anlaşılabilir olduğu kabul edildikten sonra çalışma grubu ile görüşmeler yapılmıştır.

\section{BULGULAR ve TARTIŞMA}

$\mathrm{Bu}$ bölümde, katılımcılar ile yapılmış olan görüşmeler betimsel analiz yöntemi neticesinde analiz edilmiş olup tablolar haline dönüştürülmüş ve bu tablolara ilişkin açıklamalar yapılmıştır. Ayrıca tablolardan elde edilen görüşler, ilgili çalışmalar ile tartışılarak sunulmuştur.

Tablo 2: Katılımcıların belediyenin spor politikası ile ilgili görüşleri

\begin{tabular}{ll}
\hline IFADELER & \multicolumn{1}{c}{ KATILIMCILAR } \\
\hline Beş yıllık stratejik plan doğrultusunda belirlenen bir politika & $\mathrm{K} 1$ - K2 - K3 - K4 - K5 \\
Halkı spora teşvik etmek & $\mathrm{K} 1$ - K2 - K3 - K4 - K5 \\
\hline
\end{tabular}

Katılımcılar, belediyelerinin, belediye kanunun mevzuatında yer alan 5 yıllık stratejik plan doğrultusunda, belirlenen politikalara uyulduğunu, bunun dışında kendi belediyelerine ait bir 
spor politikasının olmadığı yönünde görüş bildirmişlerdir. Bununla beraber öncelikle hedeflerinin halkı spora teşvik etmek olduğunu ifade etmişlerdir.

\section{Katılımcıların Belediyenin Spor Politikası ile İlgili Görüşleri}

K1: " Belediye olarak öncelikli politikamız; ferdi branşlara ağırlık vermek, hem il içi ve il dışı hem de uluslararası arenada yeteneklerini gösterecek yarışmacı gruplar meydana getirmek ve halkı spora teşvik etmek amacıyla yaz-kış kursları düzenlemek bunları yaparken de hizmet süremiz seçimlerle sinırlı olduğu için tüm bu faaliyetleri beş yıl sürecek olan hizmet etme süremiz çerçevesinde gerçekleştirmekteyiz.

K2: "Yeni kurulan bir ilçe belediye olduğundan Spor politikası olarak ilk hedefimiz insana hizmet etmeyi, onlara daha iyi imkânlar sunup spora teşvik etmeyi bunları yaparken plan program çerçevesinde yürütülmesini sağlamaktayız."

K3: "Öncelikle var olan şehrin spor kültürünü devam ettirme yolunda ilerlerken bunu plan program çerçevesinde spor olgusunu tüm halka aşllamak, bireysel veya profesyonel spor branşları ayrımı yapmaksızın spor faaliyetlerine en üst düzeyde destek verme düşüncesindeyiz."

K4: "Yeni kurulan başka bir ilçe belediye olduğundan politika olarak edindiğimiz spor olgusunu vatandaşlarımızın talepleri ve önerileri doğrultusunda öncelikle halkın istediği spor aktiviteleri doğrultusunda yürütme kararl aldık. Bunu yaparken diğer branşlara da ayrım gözetmeden aynı destekleri verdiğimize inanıyoruz."

K5: "Politikadan çok ilke edindiğimiz kriterler her kesimden yetenekli olan sporcuları eşitlik ve adalet çerçevesinde desteğimizi sağlamaktayız. Hizmet verirken bu konuları göz önünde bulunduruyoruz ve spor olgusunu ilçemizde sürekli artırma sürecinde tutmaktayız.

Sonuç olarak, yeni kurulan belediyelerin tüzüklerinin olmamasından dolayı belediyelerin kendilerine ait uzun vade de bir spor politikalarının olmadığı, katılımcıların çoğunlukla spor faaliyetlerine en üst düzeyde destek vermek ve halkı spora teşvik etmek düşüncesinde oldukları görülmektedir.

Kocaeli ilinde Doğu ve ark., (2013:101-102) "Büyükşehir Belediyesi Spor Politikalarına Yönelik Hizmetlerin İncelenmesi Kocaeli Büyükşehir Belediyesi Örneği” başlıklı çalışma incelendiğinde spor politikalarına yönelik araştırma sonuçları ile benzer bir sonuçla karşılaş1ldı̆̆1 görülmektedir. Kurtipek (2017: 58) "Metropoliten Alan İçerisindeki Belediyelerin Gençlik ve Spor Politikalarının Değerlendirilmesi” başlıklı çalışmasında, spor politikalarında öncelikli amaçlarının gençleri sportif faaliyetlere yönlendirmek ve herkes için spor anlayışının gerçekleşmesi yönünde olduğudur. Bu bağlamda, çalışmalar incelendiğinde genel olarak belediyelerin stratejik planlar doğrultusunda spor politikaları oluşturduklarını, kendine özgü politikalarının olmadığını, bununla birlikte belediyelerin öncelikli hedeflerinin herkes için sporu önemsemek ve spor bilincini yayma düşüncesi olduğunu söylemek mümkündür. 
Tablo 3: Katılımcıların belediyenin spor hizmetleri ile ilgili görüşleri

\begin{tabular}{|c|c|}
\hline İFADELER & KATILIMCILAR \\
\hline Sporu tabana yayma projeleri & K1 - K2 - K3 - K4 - K5 \\
\hline Malzeme yardımı & K1 - K2 - K3 - K4 - K5 \\
\hline $\begin{array}{l}\text { Halkın taleplerinin ölçümlerle } \\
\text { belirlenmesi }\end{array}$ & K1 - K3 \\
\hline Futbol ağırlıklı spor hizmeti anlayışı & $\mathrm{K} 1-\mathrm{K} 2-\mathrm{K} 3$ - K4 - K5 \\
\hline Farklı branşları tanıtma projeleri & K1 - K2 - K3 -K5 \\
\hline $\begin{array}{l}\text { Talepler doğrultusunda hizmet } \\
\text { verilmesi }\end{array}$ & K1 - K3 - K4 - K5 \\
\hline Yeni Tesis & K1 - K2 - K3 - K4 - K5 \\
\hline Kadınlara özel çalışma salonları & K2 - K3 \\
\hline
\end{tabular}

Tablo 3 incelendiğinde; Katılımcı görüşlerine göre, beş katılımcı sporu tabana yayma projeleri, malzeme yardımı, futbol ağırlıklı spor hizmeti anlayışına sahip olduklarını ve yeni tesis sağladıklarını belirtmişlerdir.

\section{Katılımcıların Belediyenin Spor Hizmetleri ile İlgili Görüşleri}

Sporu tabana yayma projeleri ile ilgili olarak katılımcı görüșleri:

K1:"Sporu taban yayma projeleri çerçevesinde on üç farkl branşta spor hizmeti verilmektedir. Bunların yanı sıra yaz-kış devam eden basketbol ve futbol kulüplerimizde kurslarımız verilmektedir. Ayrıca yüzme alanının halka açık kapalı havuz tesislerimiz bulunmaktadır."

K2:"Belediye olarak projelerimizde önceliğimiz küçük yaşta çocukların sporla buluşmast ve bu çocukların yeteneklerinin ortaya çıkmasını să̆lamak üzere çalışmalarımızı yürütmekteyiz."

K3:"Yaş sınırı koymadan tüm halkımızla doğa yürüyüşleri, bisiklet turları, şenlik adı altında spor aktiviteleri düzenlenmektedir. Rekabetin artması yönünde çok kez yarışmalar düzenleniyor."

K4:"Profesyonel spor anlayışı yerine daha çok ferdi branşlara ağırlık vermeyi tercih ediyoruz. Bu bağlamda okullarla, halkımızın talepleriyle hareket edip spor alanın aktif olmaya çalışlyoruz."

K5:"Okullarla sürekli iletişim halinde olup yetenekli ögrencileri kendi bünyemize dahil ediyoruz ve hem ulusal hem de uluslar arast arenada kendi yeteneklerini sergileyip alt yapıdan gelenlere örnek olmaktalar."

Malzeme yardımı ile ilgili katılımcı görüșleri:

K1: " Belediye bünyesinde spor alanın mücadele eden sporcularımızın müsabakalara giderken tüm ihtiyaçlar giderilmektedir. Malzeme, ulaşım, maddi ne ihtiyaçları varsa karşılanmaktadır." 
K2:"İster Yaz kurslarımızda olsun ister diğer farklı branşlarda bulunan spor faaliyetleri olsun hepsinde malzeme yardımı en üst düzeyde yapılmaktadır. Bununla ilgili herhangi bir yaş sinırı göz ardı edilmemektedir."

K3:"Belediyemiz amatör ve bireysel branşlarda spor faaliyetleri öncesinde ve sonrasinda hem malzeme yardımı hem de ödül törenleri düzenlenip çeşitli hediyeler sunmaktadır."

K4:"Öncelikle tüm branşlara malzeme sözü vermiştik ve bunu hem belediye bütçesinden hem de iş adamların yardımıyla gerçekleştirdik ve gerçekleştirmeye de devam etmekteyiz. Daha sonra diğer branşların kurulması ve artmasıyla aynı şekilde onlara da malzeme tedarik ettik."

K5:"Amatör ve bireysel spor faaliyetlerimize bir de Milli Eğitim Müdürlüğü'ne bağll okullarda aktif olan spor branşlarına malzeme, ulaşım ve antrenör yardımı yapıldı."

Futbol ağırlıklı spor hizmeti anlayıșıyla ilgi katılımcı görüșleri:

K1:"Manisa Büyükşshir Belediyespor adı altında 1994 yılında kurulmuş futbol takımımız mevcut. 20018-2019 sezonunda T.F.F. 2. Lig Kırmızı Grupta temsil etmiştir. Futbol branşının yanı sıra basketbol, voleybol ve judo gibi alanlarda da spor faaliyetlerini sürdürmektedir."

K2:"Yeni kurulan bir belediye olmamıza ră̆men kurmuş olduğumu futbol kulübümüz başarılar göstererek BAL Ligine yükselmiş ve daha üst gruplara çıkmak için mücadelesini sürdürmektedir."

K3:"Türkiye Süper Liginde profesyonel bir futbol takımımız mevcut. Bu futbol takımına futbolcu yetiştirmek için altyapılar kurmaktayız. Ancak diğer ferdi branşlara da ă̆ırlık vermekteyiz."

K4:"Öncelikli amacımı profesyonel kulüplerle rekabet etmek yerine sporu yayma düşüncesiyle kurduğumuz futbol kulübümüz aktif ve başarlar çerçevesinde faaliyetlerini sürdürmektedir."

K5:"Kurduğumuz futbol kulübüne alt yapıdan oyuncular seçmekteyiz. Bu da daha çok sporcunun dikkatini çekerek spor anlayışını geliştirmektedir. Yetiştirdiğimiz futbolcuları başka kulüplere yollayarak hem gelişmelerini sağllyoruz hem de ilçemize yararlı hale gelmektedir."

$\underline{\text { Yeni kurulan tesisler ile ilgili katılımcı görüșleri: }}$

K1:"Yüzme alanında sirasıyla Manisa ili Yunusemre, Salihli ve Turgutlu ilçelerinde yapılan kapalı yüzme havuzlarımız mevcuttur. Bunun yanı sıra Turgutlu ilçesi Ovacık mevkiinde tüm sporcular için yedi yüz irtifada bir kamp merkezi kurduk. İlimize gelen sporcu kafilesi için kamp ve misafirhaneden oluşan elli beş yataklık alan yarattık."

K:2 "Alt yapı futbol,amatör ve kendi belediyemizin spor kulübümüze hizmet etmek amacıyla karaali mahallesinde tesisler yapıldı. İki adet saha ölçüleri olarak F.I.F.A. standartlarına uygun tesislerimiz mevcut.Bir çok noktada da hanımlar lokali adı altında salonlar kuruldu ve fitness, plates ve step-aerobik gibi kurslar düzenlenmekte. Daha sonra Muradiye 
mahallesinde yeni yapllan spor kompleksimiz yüzme dalında hizmet vermekteler. Ortaköy ve Osmancalı mevkiinde doğa sporları ile ilgili yapımı devam eden tesislerimiz bulunmaktadır." K3:"Yeni tesis inşası olarak Gençlik ve Spor Bakanlığı'nın yaptı̆̆ı arazi kısmının tamamı belediye tarafindan tahsis edilmesiyle kurulan yeni stadyum ve bununla birlikte kapalı spor salonlarımı da mevcuttur."

K4:"Yeni kurulan bir belediye olduğumuzdan dolayı ilk süreçte illa ki kendimize ait spor tesisimiz yoktu. Öncelikle il merkezinde bulunan bedesten meydanı içerisine bayanlara özel çalışma salonu kuruldu. Yetmediği içinde yan araziyi de kiralamak zorunda kaldık. Karaağaçlı mahallesi ve Yuntdă̆ bölgesine toplamda dört adet halı sahları kuruldu. Büyükşehir Belediyesi ile birlikte ortak proje olarak Sümer park alanına spor büyük bir spor tesisi kuruldu. Arsa sıkıntımız giderildikçe bu yatırımlar yapılmaya devam edilecektir."

K5:"Turgutlu belediyespor ve yaklaşık yirmiye yakın amatör spor kulüplerine hizmet veren ilçede bulunan Irlamaz Çayı üzerine inşa edilen dört adet çim saha bir adet sentetik çim saha aynı zamanda Atatepe mevkiinde de bir adet sentetik çim sahamı bulunmaktadır. Ayrıca Gençlik ve Spor Bakanlı̆̆ tarafindan yapılan yeni spor kompleksimizde mevcuttur."

Dört katılımcı, farklı branşları tanıtım projeleri ve talepler doğrultusunda hizmetlerin verilmesi şeklinde görüş belirtmişlerdir.

$\underline{\text { Katılımcıların farklı branșları tanıtım projeleri ile ilgili görüșleri: }}$

K1:"Gençlik Spor Müdürlüğ̈̈ ile birlikte dağcllık ve bisiklet faaliyetleri düzenlendi. Ayrlca milli takımda mücadele eden jimnastik dalında Ayşe Begüm Onbaşı sporcumuz diğer alt yapıdaki sporcularımıza başarısı ve kalitesiyle örnek olmaktadır."

K2: "Futbol hariç diğer amatör ve ferdi branşlar; judo, tekvando gibi spor faaliyetleri ayrıca bayanlara özel spor salonları, kulüpleri ve lokalleri açtık.Bunların artması ve halkı daha çok spora teşvik etmek amacıyla reklam ve duyurular yaptık."

K3:"Küçük büyük yaş ayrımı yapmadan doğa yürüyüşleri, bisiklet turları, dağcılık gibi spor aktiviteleri yapılmakta ve bunun yanı sıra bocce, masa tenisi, satranç, halk oyunları gibi spor faaliyetleri de düzenlenmektedir."

K5:"Belediye olarak voleybol, basketbol, hentbol gibi spor branşların artmast ve sporcu yetiştirmek için sürekli kurs ve organizasyonlar düzenlenmektedir."

Talepler doğrultusunda hizmetlerin verilmesi ile ilgi katılımcıların görüşleri:

K1:"Çoğunlukla halk bizle iletişime geçiyor. Onların isteklerine cevap vermeye çalışlyoruz. Yüzme havuzlarımızda kurslar düzenliyoruz. Yaz-kış devam eden antrenör eşliğinde spor çalışmalarımız oluyor."

K3:"Belediye ile Celal Bayar Üniversitesi Spor Bilimleri Fakültesindeki ögrretim elemanları ile ortak yürüttüğümüz hatta veri halinde kitaba dönüş̧ürülen iki bin üç yüz yirmi kişi 
üzerinde yapılan atletik performanslarını ölçerek yetenek taraması yapıldı. Tüm aileler bu olaya davet edildi ve ondan sonra spora olan ilgi kat ve kat arttı̆̆ gözlemlendi."

K4:"Yeni kurulan bir belediye sözünü tekrarlamaktan dolayı öncelikle halkın istek ve önerilerine baktık, inceledik ve ona göre ilk adımı attık. Bayanlara özel çalışma salonları kurduk. Dĭ̆er branşlara ă̆ırlık verdik."

K5:"Spor alanında aktif olan bir belediye olduğumuzdan dolayı spor kültürümüzün de geliştiğine inanıyorum. Halkın istekleri, talepleri bizi spor alanında diğer farklı branşlara yönlendirmekte ve biz bunun devamlı takipçisi ve hizmetçisi olacağız."

Katılımcı görüşleri değerlendirildiğinde, Büyükşehir Belediyeleri tarafından sporun tabana yayılması için bir takım projeler yürütüldügü görümektedir. Katılımcılar, ilçeye ve her okula malzeme yardımı yaptıklarını ifade etmişlerdir. Böylelikle çocukların spora daha kolay ulaşacağı ve aktivitelerin daha iyi şartlarda yapılacağı düşünülmektedir. Aynı zamanda belediyeler, farklı organizasyonlar ve müsabakalar düzenlenmekte olduklarını ifade etmektedirler. Halkın talepleri çeşitli ölçümlerle dikkate alınıp değerlendirildiği ve sonuca ulaşmada çalışmalar yapıldığı ifade edilmiştir. Katılımcı görüşleri değelendirildiğinde, belediyelerin daha çok futbol ağırlıklı bir hizmet anlayışı olduğu ortaya çıkmıştır. Farklı branşların tanınması adına çalışmalar yapılabileceği fakat talebe göre hareket etmenin belediyenin bakış açısına daha uygun olduğu söylenmiştir. Katılımcılar, aynı zamanda, bazı ilçelerde bocce, güreş, satranç ve masa tenisi gibi branşlara yönelik yatırımlar ve faaliyetler yürüttüklerini ifade etmektedirler. Büyükşehir Belediye Başkanı liderliğinde spor, doğa ve bisiklet yürüyüşleri düzenlenmektedir. Artan talep ve nüfusa bağlı yeni tesislerin kurulması bunun için yeni arsaların bulunması için çalışmaların sürdüğü söylenmektedir. Ayrıca, katılımcı görüşlerine göre, kadınlara özel çalışma salonları, kursları ve spor faaliyetleri ön plana çıkmaktadır.

Kurtipek (2017:66-67) çalışmasında, görüşmeye katılan katılımcıların, belediyelerin gençlik ve spor hizmetlerinde bir değişiklik olmadığı, amatör spor kulüplerine yardımın kolaylaştığı, görev yükünün arttı̆̆1 ve kaynakların azaldığı yönünde görüş bildirdiklerini ifade etmektedir.

Doğu ve ark (2013:102-103)' nın çalışmasında da çalışma ile benzer şekilde, belediyenin spora teşvik edici çalışmalar yürüttükleri, malzeme yardımı yaptıkları, branşların tanıtımına destek oldukları görülmüştür. Tekin (2013:65-66) "Yerel Yönetimlerin Spor Hizmetlerine İlişkin Halkın Görüşleri (Keçiören Belediyesi Örneği)” başlıklı çalışmasında, katılımcıların tamamına yakınının, insanların spor ve rekreasyonel etkinlik ihtiyacının karşılanması gerektiği ve spor hizmetlerinin yerine getirme görevinin belediyelere ait olduğunu ve ilçelerinde her kesimden vatandaşın kullanabileceği, içinde spor aletlerinin bulunduğu rekreasyon alanlarının olması gerektiğini düşünmektedirler.

Dinç (2019:75-89)'in "Yönetsel Açıdan Yerel Yönetimler ve Spor İlişkisi Mersin Büyükşehir Belediyesi Örneğì" isimli çalışmasında ise "Belediyelerde ideal spor ve rekreasyon hizmetleri nasıl olmalıdır" sorusuna, katılımcılar, spor ve rekreasyon hizmetlerinin tüm yaş 
gruplarındaki vatandaşlara ulaştırılması ve yaygınlaştırılması, bu konuda gerekli iş ve işlemlerin gerçekleştirilmesi gerektiğini belirtmişlerdir. Küçük yaşlardan itibaren sporcu keşfinin yapılabilmesi ve sporcuların yetiştirilebilmesi için alt yapı faaliyetleri kapsamında etkinliklerin artırılması gerektiği düşünülmektedir. Ayrıca sporun topluma yaygınlaştırılmasında ve halkın spor ve rekreasyonel anlamda istek ve ihtiyaçlarının karşılanması konusunda katılımcılardan elde edilen verilere göre, Mersin Büyükşehir Belediyesi bünyesinde düzenlenen spor etkinlikleri belirgin bir şekilde ortaya çıkmaktadır. Rekreasyon alanlarında bilinçli spor yaptırarak halkın spor ve rekreasyonel anlamda istek ve ihtiyaçlarının karşılandığı düşünülmekte olup araştırmanın sonuçları ile benzerlik göstermektedir.

Sonuç olarak belediyelerin kendi bölgelerine, nüfuslarına, ilin beklentilerine, bulundukları coğrafi özelliklerine, iklimine ve diğer unsurlar göz önüne alınarak bunlara yönelik olarak farklı hizmetler verdikleri söylenebilmektedir.

Tablo 4. Katılımcıların kurum ve kuruluşlarla iş birliği yönündeki görüşleri

\begin{tabular}{ll}
\hline IFADELER & KATILIMCILAR \\
\hline Diğer kurum kuruluşlarla (GSIMM,Üniversite,STK) & K1 - K2 - K3 - K4 - K5 \\
işbirliği fikri & \\
Eşgüdüm eksikliği & K2 - K3 - K4 \\
Birimler arası iletişim eksikliği & K2 - K4 - K5 \\
Ortak proje kararlarının alınmasındaki düzensizlik & K2 - K3 - K4 \\
\hline
\end{tabular}

Katılımcının görüşlerine bakıldığında; diğer kurum ve kuruluşlarla iş birliğine önem verdikleri gözlenmektedir.

\section{Katılımcıların Kurum ve Kuruluşlarla İş Birliği Yönündeki Görüşleri}

Diğer kurum ve kurulușlarla iș birliği ile ilgili katılımcıların görüssleri:

K1: "Daha çok G.S.I.M ile iletişim halindeyiz. Diğer ortak proje olduğunda diğer kurum ve kuruluşlarla iş birliği içine girmekteyiz. Alınan kararların bir çoğu belediye tarafindan ortaya çıkmaktadır. Uygulama ve işlerlik kısmı yine belediye tarafından karşılanmaktadır."

K2: "Küçük yaştan itibaren çocuklarl spora teşvik etmek istediğimizden dolayı hem M.E.M' ne bă̆gl okullarda okuyan ögrenciler hem de G.S.I.M' ye bağll lisanslı sporcularla sürekli iletişim halinde oluyoruz. Ortak devam eden projelerimiz var. Bunlar üzerinden daha iyisi nasıl olur diye sürekli gelişim halindeyiz. Malzeme, ulaşım, antrenör gibi diğer bir çok unsur kendi kurumumuzdan sağlanmaktadır. Her kesim kendi prestij ve marka olma yolunda ilerlediğinden bazı kararlarda yalnız kalmak zorunda kalıyorsunuz."

K3: "Kaymakamlık, S.T.K., Ticaret Borsası ve Odalar Birliği, M.E.M. ile sürekli iletişim halindeyiz. Gerektiği zaman C.B.Ü. akademisyenleri ile de bir araya geliyoruz. Ancak bazen ilçe gençlik müdürlüğümüz ile karar alma ve verme konusunda sıkıntılar yaşıoruz. Bu da bazen işlerin aksamasina sebebiyet vermektedir." 
K4: "İlçe belediye olduğumuzdan büyükşehir belediyesi ile ortak yürüttügüumüz projeler oluyor. Spor salonlar, tesisler ve kiralama işlemleri ile ilgili sürekli iletişim halinde oluyoruz. Gerektiği zaman Kaymakamlık, okullar ve G.S.I.M. ile de irtibata geçiyoruz. Kendi kurumumuzda spor ile ilgili birim kurulamadı̆̆ından dolayı bazı organizasyonlar eksik kallyor ve yürütme işlemi aksaklı̆̆a uğruyor."

K5: "Belediye olarak tüm kurum ve kuruluşlarla iş birliği içerisindeyiz. Hatta geçen sene Sosyal Hizmetler Müdürlüğ̈̈ ile oradaki çocukların spor aktivitelerini daha rahat ve iyi koşullarda yapsinlar diye saha tesisi ve ardından top ile malzeme yardımı yapıldı. Ancak özellikle tesislerin kullanımı konusunda tüm sene boyunca diğer kurumlardan ziyade kendi kurumumuz ilgileniyor. Bu sebeple bazen koordine olamiyoruz ve kendi birimimizde spor alanında görev yapan personellerimiz plan ve programı yapmaktalar."

Sonuç olarak; katılımcı görüşleri sonucunda, belediyelerin diğer kurum ve kuruluşlarla (G.S.İ.M., M.E.M., Kaymakamlık, Üniversite, S.T.K.) iş birliği ve koordinasyon içerisinde oldukları görülmektedir.

Kurtipek (2017:64'in çalışması incelendiğinde, görüşmeye katılan katılımcıların, en çok üniversiteler ve sivil toplum kuruluşları ile işbirliği içerisine girdikleri yönünde görüş bildirdikleri belirlenmiştir. Katılımcıların ayrıca Kaymakamlık ve Milli Eğitim Bakanlığı ile de işbirliği içerisinde olduklarını belirttikleri elde edilen bulgularda tespit edilmiştir. Dinç (2019:82)'in "Mersin Büyükşsehir Belediyesi”" örnekleminde ise, çalışmasında spor hizmetleri konusunda paydaşlarıyla olan kurumsal ilişkilerinin yürütülmesiyle ilgili olarak bazı katılımcılar, paydaşlarla ilişkinin önemli olduğunu, ayrıca spor hizmetleri ve sporla ilgili ulusal ya da uluslar arası organizasyonlar söz konusu olduğunda Mersin Büyükşehir Belediyesi kendi yetkisi dışında kalan konularda (güvenlik vb.) paydaşlarla zorunlu olarak iletişim içerisinde olmaları gerektiği ancak özellikle kamu örgütleriyle olan işbirliklerinde bazı yandaş olmayan yöneticilerin etkili olduğu konusunda önemli rol oynadığı ifade edilmiştir. Elde edilen bir başka veriye göre paydaşlarla ilişkilerin yürütülmesinde ikili ilişkilerin ortaya çıkan problemleri aşmak ve süreci devam ettirmek üzerinde etkili olduğu, aynı zamanda kurumsal ilişkilerde protokole dayalı düzenlemelerin önem arz ettiği belirlenmiştir. Paydaşlarla yaşanan işbirliği ile ilgili sorunlarla ilişkin olarak katılımcıların mevzuattan kaynaklı problemlere ve yeterli destek verilmemesine vurgu yaptıkları görülmektedir. Burada kurum ve kuruluş değil de daha çok paydaşlar kısmına hitap edilmiş görüşler bu yönde vuku bulmuştur.

Kurtoğlu (2006:158-159)'nun çalışmasında anket verilerine bakıldığında spor hizmeti ile ilgili katılımcıların belediyelerin kent yaşamı içerisinde kendisinden spor hizmeti sunma konusundaki beklentileri orta seviyede karşılayabildiği görülmektedir. 
Tablo 5. Belediyenin spor örgüt yapısı

\begin{tabular}{ll}
\hline İFADELER & KATILIMCILAR \\
\hline Mevcut yapının eksikliği & K1 - K3 - K4 \\
Koordinasyon eksikliği & K3 - K4 \\
İdari yapıdaki aksaklıklar & K2 - K3 - K4 - K5 \\
Gençlik spor daire başkanlığı oluşturma fikri & K1 - K2 - K3 - K4 - K5 \\
İdari kadronun alan uzmanlarından oluşmadığı fikri & K2 - K3 - K4 \\
\hline
\end{tabular}

Tablo 5 incelendiğinde, katılımcıların kurumlarında Gençlik Spor Daire Başkanlığı oluşturma fikrinde birleştikleri görülmektedir. Diğer görüşlerde ise bazı aksaklıklar ön plana çıkmaktadır.

\section{Belediyenin Spor Örgüt Yapısı İle İlgili Katılımcı Görüşleri}

K1: "Büyükşehir belediyesi olarak diğer belediyelere klyasla spor ile ilgili birimimiz onlardan çok daha ileridedir. Şuan ki birim yani Gençlik ve Spor Müdürlügü birimi daha önceden kurulmamıştı. Büyükşehir olduğumuzda bu birim Sosyal Hizmetler Daire başkanliğ adı altında Gençlik ve Spor Müdürlüğü olarak kuruldu ve faaliyet göstermektedir."

K2:"Yeni kurulan ilçe belediye olarak şuan ki mevcut kadromuzun iyi olduğu kanaatindeyim. Ancak yeterli olduğunu sanmıyorum. İsteriz ki idari kadromuz sadece sporla ilgilenen kişilerden olsun ve buna bağlı olarak bir Spor Daire Başkanlı̆̆ birimi kurulsun. En azından bu alandaki aksaklıklarl gidermiş oluruz. Yoksa kendi birimimiz içerisinde koordinasyon eksikliğimiz hiç olmadı."

K3:"Kurumumuzda çalışan personellerimize baktı̆̆ımızda sayımız yeterli değil. Tüm spor branşlarının idare kısmiyla ilgilenen bir birim neden kurulmasın? Biz bunu istiyoruz tabi ki de. Alanında uzman kimselerin varlı̆̆ hem birimlerimiz arasında ki çalışmalarımızın koordineli olarak ilerlemesini sağlar hem de idari kısmımızda ki aksaklıklarımı da giderilmiş olur."

K4:"Şuan ki spor servisi birimimiz Kültür ve Sosyal Işsler Daire Başkanlı̆̆ tarafindan yürütülmekte. Illerleyen zamanlarda eminim ki kurumumuz bu eksik olan spor biriminin kurulması ile ilgili olayın üzerine yoğunlaşır ve Gençlik Spor Daire Başkanlığı gibi bir birim kurarlar ve alanında uzman kişilerin de bulunduğu bir idari yapı kurarlar."

K5:"Bizim spor ile ilgili örgütlenme yapımızda çok eksiğimizin olduğu düşüncesinde değilim. Belediye olarak spor konusunda her türlü desteği să̆lamış durumdayız. Diğer birimlerinde istediği gibi sadece sporla ilgilenen bir birimin kurulmasını isteriz. Bu da hizmet kalitesi yönünden daha iyi olacă̆ı düşüncesindeyim."

Sonuç olarak; kurumlar içerisinde spor; Kültür ve Sosyal İşler Daire Başkanlığı ve Gençlik ve Spor Şube müdürlügü ile yönetilmektedir. Mevcut yapının koordinasyon, alan uzmanlarının eksikliği ve idari yapının işlerliğindeki aksaklıklar gibi eksiklikleri ön plana çıkmaktadır. Yeni kurulan ilçe belediyelerdeki birçok nedenden kaynaklı eksikliklerinin bulunmasından dolayı alınan kararların tutarlı olmayışı bu yapıda ciddi sıkıntıların ortaya çıktığının göstergesi olduğu düşünülmektedir. Ayrıca belediyenin idari kadrosunda görev alan personellerin alanlarında uzman olması gerektiği belirtilmiştir. Katılımcı görüşlerine 
göre, yönetim kadrosu açısından bakıldığında Gençlik ve Spor Daire Başkanlığı oluşturulması gerektiği fikri şu anki mevcut sınırlamalardan dolayı oluşturulamamaktadır.

Dinç (2019:80-81)'in çalışmasında; katılımcıların Mersin Büyükşehir Belediyesinde daha önce Gençlik ve Spor Daire Başkanlığı'nın kurulduğunu ancak ilgili dairenin mevzuat ve bütçe ile ilgili konulardan dolayı kapandığını ifade etmişlerdir.

Kurtipek'in (2017:64-64) çalışmasında da, araştırma sonuçları ile benzer şekilde belediyelerde gençlik ve spor hizmetlerinin farklı birimlere bağlı olarak yürütüldüğü görülmektedir.

Doğu ve ark., (2013:101) çalışması incelendiğinde ise, yine araştırma sonuçları ile benzerliği olan ifadelere yer verildiği görülmektedir. $\mathrm{Bu}$ ifadeler, belediyelerin mevcut yapıları içerisinde sporun farklı birimlere bağlı olarak yürütüldüğü ve bu durumun bir çok eksiklikleri beraberinde getirdiği dolayısıyla bu hizmet birimlerinin yeniden ele alınarak, her belediye teşkilatında gençlik ve spor müdürlüğünün ayrı bir birim olarak teşkil edilmesi gerekliliğidir.

Tablo 6: Tesisler ile ilgili katılımcı görüșleri

\begin{tabular}{ll}
\hline IFADELER & KATILIMCILAR \\
\hline Tesis yetersizliği & $\mathrm{K} 2$ - K3 - K4 \\
Futbol alanlarının fazlalı̆̆1 & $\mathrm{K} 1$ - K2 - K3 - K4 - K5 \\
Büyük bir spor alanı oluşturulması fikri & $\mathrm{K} 1$ - K2 - K3 - K4 - K5 \\
Düzensiz, gelişi güzel tesis yapımı & $\mathrm{K} 2$ - K3 - K4 \\
Tesis giderlerinin belediye tarafından karşılanması & $\mathrm{K} 1$ - K2 - K3 - K4 - K5 \\
Tesis yapım kararlarını alan birim yanlışlığ1 & $\mathrm{K} 3-\mathrm{K} 4$ - K5 \\
Tesis işletilmesindeki birimler arası koordinasyon eksikliği & $\mathrm{K} 1$ - K3 - K4 - K5
\end{tabular}

Tesisler ile ilgili katılımcı görüşleri incelendiğinde, beş katılımcının "büyük bir spor alanı oluşturulması, futbol alanlarının fazlalığı ve tesis giderlerinin belediye tarafından karşılanması" ifadelerinde fikir birliğine vardıkları görülmektedir.

\section{Tesisler İle İlgili Katılımcı Görüşleri}

K1: "Her il ve ilçede olduğu gibi futbol alanlarının, yatırımlarının fazla olduğunu görmekteyiz. Yapılan tüm tesisler futbol branşına ă̆ırlık verildiğinin göstergesidir. Ancak tüm spor aktivitelerin yapılacağı büyük bir alan oluşturulsun isteriz. Tabi ki de yapılan ve yapılacak olan bu tesislerin giderlerinin sadece belediye tarafindan karşılanması yerine diğer kurum ve kuruluşların hatta G.S.B. ve G.S.I.M' nünde el atmasını istiyoruz."

K2:"Belediye olarak Belediye Başkanımız da dahil isteğimiz büyük bir alan kurulsun ve tüm ferdi branşların sporlarını daha iyi ve daha kaliteli bir ortamda yapsınlar isteriz. Bakıldı Ц̆ zaman tüm kurumlar futbola ve futbol kulübü kurma düşüncesine girmişler. Yatırımlarını da ona göre yapmışlar. Ancak bu tesislerin giderleri hep belediye tarafindan karşılanıyor."

K3:"Tesis giderleri kurum olarak hep cebimizden çıkıyor. Biz bundan şikâyetçi değiliz ancak diğer kurum ve kuruluşlar maddi olarak destek vermiyorlar. Ancak çoğunun futbol alanları 
var. İlçemize baktı̆̆ımızda da kültürümüz ve futbol üzerine kurulu. Ancak amatör ve ferdi branşlarda artış göstermekler. Bunlar için büyük bir salon ya da alan kurulsun isteriz."

K4: "İlimizde diğer branşlardan çok futbol alanları mevcut. Hall sahalar, stadyumlar, alt yapı tesisleri hepsi futbol alanı. Diğer ferdi branş ve amatör spor ve sporcuların spor yapacă̆ı büyük bir alanın kurulması eminim ki şehrimizi rahatlatacaktır ve spora olan teşvik artacaktır. Bizde ve diğer kurumlarda da olduğu gibi kullandığımız ve kiraladığımız tüm sahaların giderleri kendi kurumumuzdan çıkmaktadır."

K5:"Yapılan ve yapılacak olan tüm tesislerin giderlerini biz karşıllyoruz. Diğer kurumlar bu konuda sessiz kalmaktalar. Futbol kulübümüzün ve altyapı kulüplerin birlikte oynayacă̆l, antrenman yapacă̆ $\mathrm{l}$ bir alan oluşturmak istiyoruz."

Tesislerin yetersizliği ve Düzensiz, geliși güzel tesis yapımı ile ilgili katılımcı görüșleri:

K2: "Yeni ilçe belediyesi olarak ilk etapta tesis yetersizliğinden şikâyetçiydik. Diğer kurumların plan program çerçevesinde bize ayıracak alanları yok denecek kadar azdı."

K3:"Amatör ve diğer branş sporu ve sporcularl için tesislerimiz yetersizdir. Var olanlar sinırlı branşlara ev sahipliği yapmaktadır."

K4:"Tesisler yetersiz bunun yanında arsa, arazi sıkıntımız da var. Gideremediğimiz için kiralama yoluna gidiyoruz."

Düzensiz, geliși güzel tesis yapımı ile ilgili katılımcı görüșleri:

K2: "Kimi sahalarımız idari yönünden bakım onarım eksikliğinden dolayı atıl duruma gelmiş kimileri de tam kapasiteli çalışmıyor ve düzensizler."

K3: "Mevcut tesislerimiz bazıları eski zamandan kaldı̆̆ı için alt yapı ve diğer unsurlar sürekli arıza çıkartıyorlar"

K4: "Bazı branşların oynamaya müsait olmadı̆̆ı spor salonlarımız var."

Katılımcı görüşlerine göre, genel olarak tesislerin yeterli olmadığı, var olan tesislerin ise futbol branşı üzerine yoğunlaştığ1 görülmektedir. Şehrin belirli bölgelerine ise koşu, piknik alanları, uzun yürüyüş alanları ve bisiklet parkurları yapıldığı ifade edilmektedir. Bir başka görüş ise yapılacak tesislerin dağınık olmasının yanı sıra yeni ve büyük spor alanının oluşturulma fikridir. Ayrıca yapılan tesislerin idari ve işletilmesi konusunda da büyük sıkıntılar yaşandığı sonucu ortaya çıkmıştır. Personel temininde bulunması, gelir ve giderlerin karşılanması ve bakım - onarım ihtiyaçlarının büyük bir bölümünü tesisin yapımı sonra erdikten sonra da belediye tarafından karşılandığı ortaya çıkmaktadır. Birtakım ciddi sorunlardan birisi de tesisin yapım kararının farklı birimden çıkmasıdır. Yapılan projenin uzman birim tarafindan takip edilemeyişi, yapısal olarak verimsiz amaca uygun olmayan tesislerin oluşmasına sebebiyet vermektedir. Bu nedenle tesis yapımı düzensiz, kullanışsız ve gelişi güzel olmaktadır. Bazı tesisler ise çok uzun zaman öncesinden yapıldığı için alt yapı ve diğer unsurların sürekli arıza göstermesi de bu sebebin en büyük göstergesidir. Tesisin yapılması ile ilgili alınan kararın ve bitiminden sonra da tesisin nasıl işletileceği ile ilgili 
kısmının planlanmamasından ve işleyişi hakkında meydana gelen sıkıntıların ve bu sıkıntıların çözümünün güçlüğünden söz edilmiş ve bu sebeplerden dolayı birçok tesisisin atıl hale geldiği söylenmiştir. Ortaya çıkan bu durum birimler ve kurumlararası koordinasyonun ve iletişimin zayıf olduğu sonucunu ortaya koymuştur.

Dinç (2019:83-89), çalışmasında araştırmaya katılan katılımcıların, Mersin Büyükşehir Belediyesinin spor yatırımlarına yönelik olarak tesisleşmeye verdiği öneme vurgu yapmışlardır. Öyle ki tüm ilçelerde büyükşehir belediyesi olarak çeşitli branşlarda spor tesisleri yapıldığı, bu tesislerin profesyonel sporlara uygun şekilde gerçekleştirildiği ve gençlerin spor yapabileceği alanlar oluşturduğunu ifade etmişlerdir. Katılımcıların bir kısmının da ortaya koyduğu verilerde ise tesislerin yeterli olmadığı dolayısıyla spor yatırımlarında yeteri seviyelere ulaşılamadığ 1 sonucu ortaya konulmaktadır. Araştırmada elde edilen diğer bir sonuca göre de sportif hizmetlerin yürütülmesinde diğer kamu kurum ve kuruluşlarının tesislerinin kiralanması yöntemine gidilmiş ve benzer sonuçlara ulaşılmıştır. Bir diğer soru başlığında belirtilen; belediyelerde ideal spor ve rekreasyon hizmetleri nasıl olması gerektiği yönünde katılımcılar, spor ve rekreasyon hizmetlerin tüm yaş gruplarındaki vatandaşlara ulaştırılması ve yaygınlaştırılması, bu konuda gerekli iş ve işılemlerin gerçekleştirilmesi gerektiğini belirtmişlerdir. Son olarak çalışmada elde edilen bir bulgu ise spor alanlarının çoğaltılması ve bu anlamda vatandaşların spor hizmetlerine daha hızlı ve kolay ulaşabilmesinin sağlayabilmesi için spor yapabilecekleri alanların nitelik ve sayısının artırılması gerektiğidir.

Kurtoğlu (2006:158-159) "Halkın Yerel Yönetimlerden Spor Hizmetleri Konusunda Beklentileri Mersin Örneği” başlıklı çalışmasında, anket verilerine bakıldığında katılımcıların belediyelerin spor hizmeti sunma konusunda; tesisleri yaptıkları ve daha sonar bu tesisleri kaderlerine terk ettikleri belirtilmektedir. Ayrıca, tesislerin araç-gereç eksiğini gidermedikleri, bakım ve onarımlarını yapmadıkları, tesislerde spor uzmanı istihdam etmediklerini belirtmişlerdir.

Doğu ve ark., (2013:101) "Büyükşehir Belediyesi Spor Politikalarına Yönelik Hizmetlerin İncelenmesi Kocaeli Büyükşehir Belediyesi Örneği”" başlıklı çalışmada ise tesislerin yetersizliği ve bu konuda atıl tesislerin olduğu bunun önemli sebeplerinden bazıları ise düzensi ve gelişi güzel tesislerin yapılması fikridir. $\mathrm{Bu}$ bağlamda bu çalışma ile benzer sonuçlar ortaya konmaktadır.

Kurtipek (2017:68-69) "Metropoliten Alan İçerisindeki Belediyelerin Gençlik ve Spor Politikalarının Değerlendirilmesi” çalışmasında; mevcut spor tesis ve alanlarının durumu incelendiğinde; katılımcıların neredeyse tamamı mevcut tesis ve alanların yeterli olmadığ yönünde görüş bildirmişlerdir. Ayrıca katılımcıların büyük çoğunluğunun mevcut spor tesis ve alanlarının etkili ve verimli kullanıldığını ifade ederken, az sayıda katılımcının ise bu tesis ve alanların etkili ve verimli kullanılmadığını belirttikleri tespit edilmiştir. Belediyelerin yeni spor tesis ve alanlara olan ihtiyacı incelendiğinde; katılımcıların kapalı spor tesisi, çok amaçlı tesis, yüzme havuzu, stadyum ve diğer spor tesislerine ihtiyaçları olduğu yönünde görüş bildirdikleri elde edilen bulgulardan anlaşılmaktadır ve diğer çalışmalar ile benzer sonuçlar elde edilmiştir. 
Esenkaya (2010:68-70) çalışmasında, belediye semtlerindeki spor tesislerinin verimli işletilmemesi, tesislerdeki araç-gereç malzeme ve uzman personel eksikliğinden, tesislerin açık olduğu saatlerin yeterli ve uygun olmadığından, tesislere ulaşım ve verimli kullanım problemlerinin yaşanmasından, tesisleri özendirici çalışmaların olmayışından ve yeterli bilgilendirmenin yapılmamasından dolayı halkın tesislerden yeterli düzeyde yararlanmadığı sonucuna ulaşmıştır.

\section{Sonuç ve Öneriler}

\section{Sonuç}

Katılımcılar ile yapılan görüşmeler sonucunda; çalışmanın beş kategori altında toplandığı görülmektedir. Bu kategoriler sırasıyla; belediyelerin spor politikası, spor hizmetleri, kurum ve kuruluşlarla iş birliği, spor örgüt yapısı ve tesislerdir. Katılımcı görüşlerine göre, belediyelerin spor politikaları incelediğinde; öncelikli olarak halk için spor fikrini benimsedikleri ve halkın talepleri doğrultusunda onların spor ihtiyaçlarını değerlendirdikleri ve bireysel ve amatör spora destek verdikleri sonucuna ulaşılmaktadır.

Katılımcıların spor hizmetleri hakkındaki görüşlerine değerlendirildiğinde, sporu tabana yayma düşüncesinin yanı sıra malzeme, ulaşım, tesis, antrenör temin etme ve diğer ferdi branşlarda halkın taleplerine göre hareket edilmesi gerekliliği hususunda görüş bildirdikleri görülmektedir. Kurum ve kuruluşlarla iş birliği yönündeki katılımcı görüşleri incelendiğinde; kurumun işleyişindeki bazı aksaklıların iş birliği yapılan kuruluşları da etkilemekte olduğu görülmektedir. Aynı zamanda katılımcılar, diğer kurum ve kuruluşlarla daha fazla işbirliği yapılması yönünde görüş bildirmişlerdir.

Belediyelerin spor örgüt yapısı hakkındaki katılımcı görüşlerine bakıldığında ise, bütün katılımcıların, Gençlik ve Spor Daire Başkanlığı biriminin kurulmasının gerekli olduğu yönünde görüş bildirdikleri görülmektedir. Katılımcıların, tesisler hakkındaki görüşleri incelendiğinde; futbol alanlarının fazla olduğu, mevcut tesislerin yetersiz kaldığı ve düzensiz, gelişi güzel tesislerin yapılmasından dolayı da bazı tesislerin farklı branşların kullanmasına kapalı olduğu ve bazı tesislerin de atıl duruma düştüğü yönünde görüş bildirdikleri görülmektedir.

\section{Öneriler}

Katılımcı görüşleri değerlendirildiğinde, belediyelerdeki sporun işleyişi ile ilgili bir takım eksikliklerin olduğu görülmüştür. $\mathrm{Bu}$ eksikliklerin giderilmesi boyutunda belediyelere aşağıdaki öneriler sunulmuştur.

$\checkmark$ Mevcut belediye yönetimi içerisinde spor işlerini yönetmek üzere farklı bir üst yönetim birimi kurulması,

$\checkmark$ Belediyenin kurum içi birimleri arasında iyi bir organizasyoel yapı oluşturulması, 
$\checkmark$ Belediyelerin diğer kurum ve kuruluşlarla iş birliğini ve koordinasyonu sağlayacak aynı zamanda spor alanında ortak projeler gerçekleştirilmesinden sorumlu bir ekip kurulmas1,

$\checkmark$ Mevcut ve yeni yapılacak tesislerin kullanırlı̆̆ının arttırılması,

$\checkmark$ Sporun tabana yayılmasını sağlayarak herkes için spor düşüncesinin geliştirilmesi önerilmektedir.

\section{KAYNAKLAR}

Arslan, N.T. (2005). İdari ve mal paylaşım açısından merkezi yönetim yerel yönetim ilişsileri. I.Ü. Siyasal Bilgiler Fakültesi Dergisi, No: 33, s.189-208.

Bernard, H. R., Wutich, A., \& Ryan, G. W. (2016). Analyzing qualitative data: systematic approaches. SAGE Publications.

Ceyhun, S. (2008). Spor tesislerinin rekreatif açıdan kullanımı. Kastamonu Eğitim Dergisi, 16(1), s.325-332.

Dinç, F. (2019). Yönetsel açıdan yerel yönetimler ve spor iliş̧kisi (Mersin Büyükşehir Belediyesi Örneği). Ankara, Gazi Üniversitesi Sağlık Bilimleri Enstitüsü, Doktora Tezi.

Dinç, F., Çolakoğlu, T., \& Kurtipek, S. (2018). Büyükşehir belediyelerinin spor hizmetlerinde çalışmakta olan personelin kadro tanımları ve istihdam problemlerine yönelik derleme bir çalışma. Journal of Human Sciences, 15(4), s.2533-2552.

Doğu, G., Kardaş, N. T. ve Atalı, L. (2013). Büyükşehir belediyesi spor politikalarına yönelik hizmetlerin incelenmesi (Kocaeli Büyükşehir Belediyesi Örneği). Kocaeli Üniversitesi Sosyal Bilimler Dergisi, 25: $97-111$.

Esenkaya, A. (2010). Halkın yerel yönetimlerden spor hizmetleri konusunda beklentileri (Konya Örneği). Konya, Selçuk Üniversitesi, Sağlık Bilimleri Enstitüsü Yüksek Lisans Tezi.

Keleş, R., ve Yavuz, F. (1983). Yerel yönetimler. Ankara: Turhan Kitap Evi, s.20.

Kurtipek, S. (2017). Metropoliten Alan içerisindeki belediyelerin gençlik ve spor politikalarının değerlendirilmesi. Doktora Tezi, Gazi Üniversitesi Sağlık Bilimleri Enstitüsü, Ankara, s.61.

Kurtipek, S. (2019). Belediyeler ve spor politikaları. Ankara: Berikan Yayınevi, s.69.

Kurtoğlu, T. (2006). Halkın Yerel yönetimlerden spor hizmetleri konusunda beklentileri (Mersin Örneği). Mersin Üniversitesi, Sağlık Bilimleri Enstitüsü, Yüksek Lisans Tezi.

LeCompte, M. D., \& Goetz, J. P. (1982). Problems of reliability and validity in ethnographic research. Review of Educational Research, 52(1), s.31-60.

Mersinli, D. (2009). Yerel yönetimlerde spora yönelik rekreasyon hizmetleri ve büyükşehir belediyelerinin rekreasyonel faaliyetleri olan yaklaşımlarının değerlendirilmesi. Yüksek Lisans Tezi, Akdeniz Üniversitesi Sosyal Bilimler Enstitüsü, Antalya.

Nadaroğlu, H. (1994). Mahalli idareler teorisi, ekonomisi-uygulaması. İstanbul: Beta Basım Yayım Dă̆ıım A.Ş. s.213.

Parlak, B., ve Özgür, H. (2002). Avrupa Birliği ve bütünleşme sürecinde Türkiye'de yerel yönetimler. İstanbul: Alfa Yayınları, s.101-102.

Sinopluoğlu, M. B. (2011). Yerel yönetimlerin sporun kitlelere yayılmasına etkisi (Eskişehir İli Örneği). İstanbul, Marmara Üniversitesi, Sağlık Bilimleri Enstitüsü, Yüksek Lisans Tezi. 
Tekin, Y. (2013). Yerel yönetimlerin spor hizmetlerine ilişkin halkın görüşleri (Keçiören Belediyesi Örneği) Ankara Üniversitesi, Sağlık Bilimleri Enstitüsü, Yüksek Lisans Tezi.

Yıldırım, A., ve Şimşek, H. (2013). Sosyal bilimlerde nitel araştırma yöntemleri. (9. Genişletilmiş Baskı) Ankara: Seçkin Yayınevi.

\section{İnternet Kaynakları}

http://www.mevzuat.gov.tr/MevzuatMetin/1.5.5302.pdf) Erişim:05.07.2019.

https://www.mevzuat.gov.tr/MevzuatMetin/1.5.5216.pdf/) Erişim:05.07.2019.

Resmi Gazete http://www.mevzuat.gov.tr/MevzuatMetin/1.5.6360.pdf/ Erişim: 20.06.2019.

Resmi Gazete http://www.mevzuat.gov.tr/MevzuatMetin/1.3.442.pdf/ Erişim: 30.06.2019.

Resmi Gazete http://www.resmigazete.gov.tr/eskiler/2005/07/20050713-6.htm/ 5393 Erişim: 30.06.2019.

Resmi Gazete http://www.resmigazete.gov.tr/eskiler/2004/07/20040723.htm/ Erişim: 30.06.2019.

Resmi Gazete http://www.resmigazete.gov.tr/arsiv/19471.pdf/ Erişim: 30.06.2019.

Resmi Gazete http://www.mevzuat.gov.tr/MevzuatMetin/1.5.2972.pdf/ Erişim: 05.07.2019. 